\title{
Mental Disorders in Subjects with Diabetes: A Systematic Review
}

\section{Ornelas ACC ${ }^{1,2 *}$, Alves $\mathrm{VM}^{3}$, Carta $\mathrm{MG}^{4}$, Nardi $\mathrm{AE}^{5,6}$ and Kinrys $\mathrm{G}^{7}$}

${ }^{1}$ Laboratory of Panic and Respiration, Institute of Psychiatry, Universidade Federal do Rio de Janeiro, Brazil, ${ }^{2}$ Massachusetts General Hospital-Bipolar Clinic and Research Program (BCRP), Havard University, USA

${ }^{3}$ Alagoas University Federal, Institute of Psychiatry, Universidade Federal do Rio de Janeiro, Brazil

${ }^{4}$ Quality of Care and Applied Medical Technologies, Department of Public Health, Clinical and Molecular Medicine, University of Cagliari, Italy

${ }^{5}$ Laboratory of Panic and Respiration-Institute of Psychiatry, Universidade Federal do Rio de Janeiro, Brazil

${ }^{6}$ Department of Public Health, Clinical and Molecular Medicine, University of Cagliari, Italy

${ }^{7}$ MGH Clinical Trials Network and Institute (CTNI), Bipolar Clinic and Research Program (BCRP), Massachusetts General Hospital, Harvard Medical School, USA

\begin{abstract}
Depression has been a common comorbidity and reduces the quality of life, the poor glycemic control and consequently worsens the diabetes course. The goals of this systematic review are searching of a population who have higher mental disorders in type 1 and 2 patients with diabetes and if there is a direct relationship between glycemic control and psychiatric disorders in this population. A total of 2527 references, review and review articles were excluded, 19 scientific studies were selected: 9 cross-sectional studies, 6 prospective observational studies, 3 retrospective observational studies, and 1 case-control study. Depression and anxiety have a high prevalence in subjects with diabetes. Therefore, the relevance of this study is showing that those mental disorders have a direct correlation in both types of diabetes treatments and decrease the quality of life. Also, the rates of depression could be up to three times higher in patients with type 1diabetes and twice as high in individuals with type 2 diabetes compared with the general population. Patients live in fear of complications from diabetes over the long term and also have damage due to the high psychiatric comorbidity of these chronic patients.
\end{abstract}

Keywords: Mental disorder; Diabetes; Anxiety; Depression; Quality of life

\section{Introduction}

Chronic diseases cause more than $50 \%$ of deaths worldwide $[1,2]$. Furthermore, it is estimated that deaths from chronic diseases will increase by $15 \%$ in the next 10 years [1-4]. Mood and Anxiety disorders have highly prevalent conditions in diabetes and have a significant impact on health outcomes [5,6]. Most relevant lifestyle factors are related to another-physic comorbidity as well, which warrants their evaluation when examining the association between quality of life, depression and adverse health outcomes in this chronic disease [5-7]. The American Psychiatric Association Diagnostic and Statistical Manual of Mental Disorders (DSM-5) describes diabetes as a correlation of mood disorder and join several symptoms that cause severe dysfunctionality of an individual [8]. People with diabetes have considerable disadvantages in their emotions, cognition, and behaviors decreased by depression symptoms [9]. Actually, core symptoms like an irritable mood or reduced pleasure as an anhedonia or both. Therefore, feelings of guilt or worthlessness; fatigue or loss of energy; concentration problems; suicidal thoughts or ideation; weight loss or weight gain (around $5 \%$ change in weight); psychomotor retardation or change in activity like a slowdown and hypersomnia or insomnia lasting during 2 weeks are diagnostic criteria for a Major Depressive Disorder [8]. Depression could be described as a first episode, a recurrent or chronic episode; could be mild, moderate or severe, with or without psychotic features [8]. Study of depression as a predictor and it is moderately increased in undiagnosed in people who have diabetes or prediabetes, also increases the diabetes previously diagnosed compared to normal glucose metabolism individuals $[9,10]$. Anxiety appears at least, in $40 \%$ of patients with Type $1 / 2$ diabetes [10]. In study about psychiatry disorders in patients who have diabetes show of emotional disorders (29\%), depression (27\%), anxiety (47\%) and low quality of life (physical component score $=46, \mathrm{SD}=11.2$; mental component score $=36$, $\mathrm{SD}=13.9, \mathrm{p}<0.001$ for difference) [11]. Emotional distress like injury, humiliation, worry, and fear, and may curtail routine activities such as driving or socializing are pervasive and under-addressed by health care providers $[10,11]$. Therefore, the consequences are increasing their anxiety and having social episodes of hypoglycemia. Patients' family members are also negatively impacted by uncontrolled patients with Type $1 / 2$ diabetes. There is $50 \%$ risk of having a mental health problem in life, and this leads to being unemployed or unproductive people [10]. The same study described other relevant results which depression and anxiety disorders are the $4^{\text {th }}$ cause, while diabetes is the $8^{\text {th }}$ cause of disability-adjusted life years (DALYs) in developed countries. Depression was more prevalent among individuals with diabetes (20\%) when was compared with asthmatics (12\%) and patients without diabetes $(4 \%)$, while anxiety was more prevalent among asthmatics (34\%) than patients with diabetes (20\%) and healthy individuals (8\%). Predictors of depression include demographic dates, since the age of the patient, social status, poor glycemic control and duration of diabetes mellitus [10]. The goals of this study are showing the higher prevalence in psychiatric disorders and how those disorders can influence in the quality of life in patients with Type $1 / 2$ diabetes and compare if there are differences of those comorbidities in both types.

\section{Materials and Methods}

A systematic review was conducted in PubMed, Embase and ISI Web of Science, following the recommendations of the Preferred Items for Reporting of Systematic Reviews and Meta-Analyses (PRISMA)

*Corresponding author: Ana Claudia De Ornelas, Havard University, Psychiatry 113, OAKLAND ST UNIT 2, Malden, Massachusetts 02148, United States, Tel: 18575235004; E-mail: psianaornelas@gmail.com

Received November 24, 2017; Accepted December 10, 2017; Published December 17, 2017

Citation: Ornelas ACC, Alves VM, Carta MG, Nardi AE, Kinrys G (2017) Mental Disorders in Subjects with Diabetes: A Systematic Review. Health Care Current Reviews 5: 216. doi: 10.4172/2375-4273.1000216

Copyright: (C) 2017 Ornelas ACC, et al. This is an open-access article distributed under the terms of the Creative Commons Attribution License, which permits unrestricted use, distribution, and reproduction in any medium, provided the original author and source are credited. 
Citation: Ornelas ACC, Alves VM, Carta MG, Nardi AE, Kinrys G (2017) Mental Disorders in Subjects with Diabetes: A Systematic Review. Health Care Current Reviews 5: 216. doi: 10.4172/2375-4273.1000216

Page 2 of 7

statement [12]. The search terms used were "diabetes", "mental", "disorders", "depression", "anxiety", "comorbity", "quality of life" and "psychiatric". The research took place in March, 2017 and no time restriction was placed on any of database searches. Manual searches were also conducted using the reference lists from identified articles. Review and theoretical articles were excluded, and 19 scientific studies were selected.

\section{Results}

A total of 2537 references were searched in 3 data bases: 1685 Embase, 774 PubMed and 78 ISI Web of Science. A total of 349 were excluded because they were duplicates or were not in English. The abstracts of the 2188 remaining references were analyzed and after reading them 19 full text analyses were selected to write this systematic review. Those nineteen articles (Table 1) matched the inclusion criteria of "Mental disorders in subjects with diabetes: a systematic review" being an observational cohort studies, about comorbidity in mental health and including a study population of patients with Type $1 / 2$ diabetes. According to the methodological design as shown in Figure 1 , there were 9 cross-sectional studies, 6 prospective observational studies, 3 retrospective observational studies and 1 case-control study.

\begin{tabular}{|c|c|c|c|c|c|c|}
\hline Date & Authors & Title & Sample & Delimitation & $\begin{array}{c}\text { Method / } \\
\text { Instruments }\end{array}$ & Abstract \\
\hline 2011 & Chaudhry et al. [22] & $\begin{array}{l}\text { Psychiatric morbidity } \\
\text { among patients with } \\
\text { diabetes: a hospital- } \\
\text { based study }\end{array}$ & 100 & $\begin{array}{l}\text { Observational prospective } \\
\text { cohort study }\end{array}$ & $\begin{array}{l}\text { HAM-A } \\
\text { HAM-D }\end{array}$ & $\begin{array}{c}\text { Patients with diabetes are more prone to comorbid } \\
\text { disorders like depression and anxiety, } 84 \% \text { of } \\
\text { the patients had comorbid depression. Females showed } \\
\text { a high percentage of depression and anxiety than male } \\
\text { and the severity level was also higher in the females as } \\
\text { well. }\end{array}$ \\
\hline 2012 & Atlantis [29] & $\begin{array}{l}\text { Excess burden of } \\
\text { type } 1 \text { and type } \\
2 \text { diabetes due } \\
\text { topsychopathology }\end{array}$ & 48359 & $\begin{array}{c}\text { Observational retrospective } \\
\text { cohort study }\end{array}$ & $\begin{array}{c}\text { Kessler } \\
\text { Psychological } \\
\text { Distress Scale }\end{array}$ & $\begin{array}{c}\text { The prevalence of type } 2 \text { diabetes when was compared } \\
\text { with type } 1 \text { increased by } 36 \% \text { between } 2001 \text { and } 2008 \text {. } \\
\text { Odds ratios with } 95 \% \mathrm{Cl} \text { for type } 1 / 2 \text { diabetes ranged } \\
\text { from } 1.43(0.98,2.10) \text { to } 2.44(1.63,3.64) \text { and } 1.32 \\
(1.13,1.53) \text { to } 1.67(1.39,2.02) \text { for people with compared } \\
\text { to those without psychopathology. Lifestyle is a risk factor } \\
\text { to inform practice for more effective management and } \\
\text { treatment plan. }\end{array}$ \\
\hline 2012 & Maia et al. [13] & $\begin{array}{c}\text { Prevalence of } \\
\text { psychiatric disorders } \\
\text { in patients with types } 1 \\
\text { and } 2 \text { diabetes }\end{array}$ & 200 & $\begin{array}{l}\text { Observational cross- } \\
\text { sectional Cohort Study }\end{array}$ & $\begin{array}{l}\text { MINI International } \\
\text { Neuropshychiatric } \\
\text { Interview }\end{array}$ & $\begin{array}{c}\text { There is a high prevalence of psychiatric disorders } \\
\text { in patients with diabetes. The main goal of this study } \\
\text { was pointing to the need for a greater investment } \\
\text { in appropriate diagnostic evaluation of patients that } \\
\text { considers mental issues. Some mental disorders, like } \\
\text { GAD, Depression and Social Phobia are more common } \\
\text { in type } 1 \text { diabetic }\end{array}$ \\
\hline 2012 & Bener et al. [14] & $\begin{array}{l}\text { Prevalence, symptom } \\
\text { patterns and } \\
\text { comorbidity of anxiety } \\
\text { and depressive } \\
\text { disorders in primary } \\
\text { care in Qatar }\end{array}$ & 2080 & $\begin{array}{l}\text { Observational Cross } \\
\text { Sectional Cohort Study }\end{array}$ & $\begin{array}{l}\text { HADS-A } \\
\text { HADS-D }\end{array}$ & $\begin{array}{l}\text { Depression was more prevalent in the population } \\
\text { who has diabetes than anxiety disorders. Women } \\
\text { were likelier than men to have depression and } \\
\text { anxiety disorders. The high-risk groups of depression and } \\
\text { anxiety disorders were female gender, being married, } \\
\text { middle aged and highly educated. }\end{array}$ \\
\hline 2013 & Niraula et al. [15] & $\begin{array}{c}\text { Prevalence of } \\
\text { depression and } \\
\text { associated risk factors } \\
\text { among persons } \\
\text { with type-2 diabetes } \\
\text { mellitus without a prior } \\
\text { psychiatric history: a } \\
\text { cross-sectional study } \\
\text { in clinical settings in } \\
\text { urban Nepal }\end{array}$ & 385 & $\begin{array}{l}\text { Observational cross- } \\
\text { sectional Cohort Study }\end{array}$ & BDI & $\begin{array}{l}40.3 \% \text { of individuals with diabetes were depressive. This } \\
\text { study provides a primary care is essential as a treatment } \\
\text { for a causal pathway from diabetes to depression. } \\
\text { Integration of mental health services will be important } \\
\text { to combat development of depression among those } \\
\text { patients. }\end{array}$ \\
\hline 2013 & Bernstein et al. [39] & $\begin{array}{c}\text { Mental health issues } \\
\text { in adolescents and } \\
\text { young adults with type } \\
1 \text { diabetes: prevalence } \\
\text { and impact on } \\
\text { glycemic control }\end{array}$ & 150 & $\begin{array}{l}\text { Observational cross- } \\
\text { sectional cohort study }\end{array}$ & $\begin{array}{l}\text { BDI } \\
\text { Child Anxiety } \\
\text { Related Emotional } \\
\text { Disorders Inventory } \\
\text { Eating Disorder } \\
\text { Screen for Primary } \\
\text { Care Instrument }\end{array}$ & $\begin{array}{l}\text { This study supports screening for mental health issues in } \\
\text { adolescents and young adults with type } 1 \text { diabetes. More } \\
\text { than a third screened positive: } 11.3 \% \text { for depression, } \\
21.3 \% \text { for anxiety and } 20.7 \% \text { for disordered eating } \\
\text { ( } 14.7 \% \text { had } \geq 2 \text { positive screens). }\end{array}$ \\
\hline 2013 & $\begin{array}{l}\text { De Ornelas et al. } \\
\qquad 16]\end{array}$ & $\begin{array}{l}\text { Comorbidity of } \\
\text { Depression and } \\
\text { Anxiety: Association } \\
\text { with Poor Quality of } \\
\text { Life in patients with } \\
\text { Type } 1 \text { and } 2 \text { diabetes }\end{array}$ & 210 & $\begin{array}{c}\text { Observational } \\
\text { Cross-sectional Cohort } \\
\text { Study }\end{array}$ & $\begin{array}{c}\text { HADS } \\
\text { WHOQOL-BREF }\end{array}$ & $\begin{array}{c}\text { Groups showed a high prevalence of anxiety (type } \\
1=60 \% \text {, type } 2=43.8 \% \text { ) and depression (type } 1=52.4 \% \text {, } \\
\text { type } 2=38.1 \% \text { ), both measures were significantly higher } \\
(p<0.05) \text { in patients with diabetes type } 1 \text {. In overall } \\
\text { patients with diabetes depression and anxiety seems to } \\
\text { be a determinant of poor QoL. }\end{array}$ \\
\hline 2014 & $\begin{array}{c}\text { Van Dijk PR et al. } \\
{[44]}\end{array}$ & $\begin{array}{l}\text { Fifteen-year follow-up } \\
\text { of quality of life in type } \\
1 \text { diabetes mellitus }\end{array}$ & 283 & $\begin{array}{l}\text { Observational Prospective } \\
\text { cohort study }\end{array}$ & $\begin{array}{l}\text { SF-36 } \\
\text { EuroQol }\end{array}$ & $\begin{array}{l}\text { Among patients with diabetes on treatment with } \\
\text { insulin have decreased significantly over time: mental } \\
\text { component summary }[-9.8(-16.3,-3.2)] \text {, physical } \\
\text { component summary }[-8.6(-15.3,-1.8)] \text { and EuroQol- } \\
\text { VAS - scale }[-8.1(-14.0,-2.3)], P<0.05 \text { for all. }\end{array}$ \\
\hline
\end{tabular}


Citation: Ornelas ACC, Alves VM, Carta MG, Nardi AE, Kinrys G (2017) Mental Disorders in Subjects with Diabetes: A Systematic Review. Health Care Current Reviews 5: 216. doi: 10.4172/2375-4273.1000216

Page 3 of 7

\begin{tabular}{|c|c|c|c|c|c|c|}
\hline 2014 & $\begin{array}{c}\text { Dos Santos et al. } \\
{[31]}\end{array}$ & $\begin{array}{l}\text { Anxiety disorders are } \\
\text { associated with quality } \\
\text { of life impairment in } \\
\text { patients with insulin- } \\
\text { dependent type } 2 \\
\text { diabetes: a case- } \\
\text { control study }\end{array}$ & 996 & $\begin{array}{l}\text { Caso control } \\
\text { Study }\end{array}$ & $\begin{array}{l}\text { MINI International } \\
\text { Neuropsychiatric } \\
\text { Interview } \\
\text { WHOQOL-BREF }\end{array}$ & $\begin{array}{l}\text { Type } 2 \text { patients had a higher prevalence of generalized } \\
\text { anxiety disorder, panic disorder and obsessive- } \\
\text { compulsive disorder. These disorders in combination } \\
\text { with type } 2 \text { diabetes was associated with worse } \\
\text { quality of life in the physical, social, psychological and } \\
\text { environmental domains. }\end{array}$ \\
\hline 2014 & Maia et al. [17] & $\begin{array}{c}\text { Psychiatric } \\
\text { comorbidity in type } \\
1 \text { diabetes: a cross- } \\
\text { sectional observational } \\
\text { study }\end{array}$ & 110 & $\begin{array}{c}\text { Cross-sectional } \\
\text { Observational Study }\end{array}$ & $\begin{array}{l}\text { MINI International } \\
\text { Neuropsychiatric } \\
\text { Interview } \\
\text { HADS }\end{array}$ & $\begin{array}{l}\text { Prevalence of anxiety symptoms in } 60 \% \text { and } 53.6 \% \\
\text { of depression in a sample of } 110 \text { type } 1 \text { patients. The } \\
\text { most remarkable data were generalized anxiety disorder } \\
(22.7 \%) \text {, dysthymia (18.2\%), panic disorder }(8.2 \%) \text { and } \\
\text { social phobia (5.5\%). Presence of symptoms related } \\
\text { to psychopathology in patients with type } 1 \text { diabetes is } \\
\text { evident. }\end{array}$ \\
\hline 2015 & Tüzün et al. [18] & $\begin{array}{l}\text { Impact of comorbidity } \\
\text { and socioeconomic } \\
\text { status on quality of life } \\
\text { in patients with chronic } \\
\text { diseases who attend } \\
\text { primary health care } \\
\text { centers }\end{array}$ & 2560 & $\begin{array}{l}\text { Cross-sectional } \\
\text { Observational Study }\end{array}$ & $\begin{array}{l}\text { WHOQOL-BREF } \\
\text { Primary Care } \\
\text { Questionnaire }\end{array}$ & $\begin{array}{l}\text { Mental disorders and diabetes-hypertension comorbidity } \\
\text { had the most negative effect on the QoL. The effect } \\
\text { of diabetes-hypertension comorbidity is greater than the } \\
\text { additive effect of hypertension and diabetes individually. }\end{array}$ \\
\hline 2015 & Handley et al. [19] & $\begin{array}{c}\text { Suicidal ideation } \\
\text { reported by adults } \\
\text { with Type } 1 \text { or Type } \\
2 \text { diabetes: Results } \\
\text { from Diabetes MILES- } \\
\text { Australia }\end{array}$ & 3338 & $\begin{array}{l}\text { Observational cross- } \\
\text { sectional cohort Study }\end{array}$ & $\begin{array}{l}\text { Problem Areas } \\
\text { In Diabetes scale } \\
\text { Patient Health } \\
\text { Questionnaire }\end{array}$ & $\begin{array}{c}\text { Type } 2 \text { diabetes patients using insulin reported more } \\
\text { frequent depressive symptoms, and were more likely } \\
\text { to report recent Suicide Ideation (19\%) compared with } \\
\text { those with either Type } 1 / 2 \text { diabetes patients not using } \\
\text { insulin ( } 14 \text { and } 12 \% \text {, respectively). }\end{array}$ \\
\hline 2015 & Gemeay et al. [30] & $\begin{array}{c}\text { The association } \\
\text { between diabetes and } \\
\text { depression }\end{array}$ & 100 & $\begin{array}{l}\text { Retrospective Cohort } \\
\text { Observational Study }\end{array}$ & $\begin{array}{l}\text { MINI International } \\
\text { Neuropsychiatric } \\
\text { Interview } \\
\text { BDI }\end{array}$ & $\begin{array}{l}\text { More than } 37 \% \text { individuals with type } 1 / 2 \text { in diabetes } \\
\text { had depression. This study revealed that there is an } \\
\text { association between diabetes and depression although } \\
\text { the correlation between depression and diabetes was } \\
\text { not significant is this study, while there was found a } \\
\text { significant relation with changes in body image. }\end{array}$ \\
\hline 2015 & Bajor et al. [23] & $\begin{array}{l}\text { Associations between } \\
\text { comorbid anxiety, } \\
\text { diabetes control and } \\
\text { overall medical burden } \\
\text { in patients with serious } \\
\text { mental illness and } \\
\text { diabetes }\end{array}$ & 157 & $\begin{array}{l}\text { Prospective Cohort } \\
\text { Observational Study }\end{array}$ & $\begin{array}{l}\text { Self-Reported } \\
\text { Charlson Index } \\
\text { MINI International } \\
\text { Neuropsychiatric } \\
\quad \text { Interview }\end{array}$ & $\begin{array}{l}33.1 \% \text { of Individuals who have anxiety disorders were } \\
\text { with serious mental illness and type } 2 \text { diabetes and } \\
\text { were associated with increased severity of depressive } \\
\text { symptoms and decreased function. }\end{array}$ \\
\hline 2016 & $\begin{array}{l}\text { van Dooren et al. } \\
\text { [20] }\end{array}$ & $\begin{array}{l}\text { Psychological and } \\
\text { personality factors } \\
\text { in type } 2 \text { diabetes } \\
\text { mellitus, presenting } \\
\text { the rationale and } \\
\text { exploratory results } \\
\text { from The Maastricht } \\
\text { Study, a population- } \\
\text { based cohort study }\end{array}$ & 864 & $\begin{array}{l}\text { Cross-sectional } \\
\text { Observational Study }\end{array}$ & $\begin{array}{l}\text { Mini International } \\
\text { Neuropsychiatric } \\
\text { Interview } \\
\text { PHQ-9 } \\
\text { Generalized Anxiety } \\
\text { Disorder Scale } \\
\text { Dutch Personality } \\
\text { Disorder Scale }\end{array}$ & $\begin{array}{l}\text { Study found more psychological distress and has } \\
\text { different personality in patients with diabetes type } \\
2 \text { compared to the general population. Type } 2 \text { diabetes } \\
\text { self-management is known to be burdensome, as it } \\
\text { requires discipline and perseverance to adapt every } \\
\text { day activities (diet, exercise, rest) to medication use and } \\
\text { glucose levels and Insulin therapy, particularly, may be } \\
\text { associated with increased psychological distress. }\end{array}$ \\
\hline 2016 & Shin et al. [24] & $\begin{array}{c}\text { Help-seeking } \\
\text { behaviors for serious } \\
\text { psychological distress } \\
\text { among individuals } \\
\text { with diabetes mellitus: } \\
\text { The California Health } \\
\text { Interview Survey, } \\
2011-2012\end{array}$ & 40803 & $\begin{array}{l}\text { Prospective Cohort } \\
\text { Observational Study }\end{array}$ & $\begin{array}{l}\text { California Health } \\
\text { Interview Survey }\end{array}$ & $\begin{array}{l}\text { The prevalence of Diabetes and psychological distress } \\
\text { were } 10.9 \% \text { and } 3.4 \% \text {, respectively, among participants } \\
\text { in this research. The patients with Diabetes were more } \\
\text { likely to experience serious psychological distress than } \\
\text { those without Diabetes (OR 1.46, } 95 \% \mathrm{Cl}=1.11-1.91 \text {, } \\
\qquad \mathrm{p}=0.006) .\end{array}$ \\
\hline 2016 & Chien and Lin [25] & $\begin{array}{c}\text { Increased risk of } \\
\text { diabetes in patients } \\
\text { with anxiety disorders: } \\
\text { A population-based } \\
\text { study }\end{array}$ & 1000000 & $\begin{array}{l}\text { Prospective Cohort } \\
\text { Observational Study }\end{array}$ & NHRI (data bases) & $\begin{array}{l}\text { In patients with diabetes, anxiety disorders were } \\
\text { higher than that in the general population }(11.89 \% \\
\text { vs. } 5.92 \% \text {, odds ratio, } 1.23 ; 95 \% \text { confidence interval, } \\
1.17-1.28) \text { in } 2005 \text {. The average annual incidence } \\
\text { of diabetes in patients with anxiety disorders was also } \\
\text { higher compared to the general population }(2.25 \% \\
\text { vs. } 1.11 \% \text {, risk ratio } 1.34 ; 95 \% \text { confidence interval, } \\
1.28-1.41) \text { from } 2006 \text { to } 2010 \text {. Patients with anxiety } \\
\text { disorders revealed a higher incidence of diabetes in all } \\
\text { age groups among both females and males. }\end{array}$ \\
\hline 2016 & Garcia et al. [26] & $\begin{array}{l}\text { Diabetes Mellitus } \\
\text { as a Risk Factor } \\
\text { for Development of } \\
\text { Depressive Symptoms } \\
\text { in a Population-Based } \\
\text { Cohort of Older } \\
\text { Mexican Americans }\end{array}$ & 1586 & $\begin{array}{l}\text { Prospective Cohort } \\
\text { Observational Study }\end{array}$ & $\begin{array}{l}\text { Center for } \\
\text { Epidemiologic } \\
\text { Studies Depression } \\
\text { Scale (CES-D) }\end{array}$ & $\begin{array}{l}\text { Diabetes mellitus increased the risk of developing de- } \\
\text { pressive symptoms in older Mexican Americans. } \\
\text { Older Latinos with diabetes mellitus. They should be } \\
\text { screened for depressive symptoms and prioritized for } \\
\text { close follow-up, potentially through greater reliance on } \\
\text { team-based models of care. }\end{array}$ \\
\hline
\end{tabular}

Table 1: Published studies based on Mental disorders in subjects with diabetes: a systematic review. 



Figure 1: Results of the systematic review in "The higher prevalence of mental disorders in diabetic patients".

\section{Cross-sectional studies [9]}

Maia et al. [13] discovered that of the 200 patients with diabetes who presented each of the psychiatric disorders identified, with percentages in decreasing order, like $21 \%$ of them had GAD (Generalized anxiety disorder); $15 \%$ dysthimia; $7 \%$ social phobia; $5.5 \%$ current depression; $2.5 \%$ panic disorder and $2 \%$ risk of suicide. Of the 200 patients $42.5 \%$ were found to have at least 1 psychiatric disorder [13]. In the same year, researchers studied about anxiety symptom in patients with diabetes and HADS-A scores were $4.1 \pm 3.6$ for males and $4.9 \pm 3.7$ for females $(p=0.048)$ and with a prevalence of $18.7 \%$ among males and $24.6 \%$ among females $(p=0.017)$, HADS-D depressive symptom scores were $8.0 \pm 6.3$ for males and $10.8 \pm 7.5$ for females $(p=0.041)$ and with a prevalence of $26.6 \%$ among males and $30.1 \%$ among females $(p=0.219)$. There are evidences that depression has a higher risk in femme population (53.1 vs. $46.9 \%)$ and anxiety disorder (56.7 vs. $43.3 \%$ ) as compared to men. Results were for anxiety (56.7\%) and depression (53.1\%) in women group who was 18-34 years [14]. Niraula et al. [15] showed in 385 patients with diabetes and clinical depression was $40.3 \%$ of the total sample. Among those depressed patients, $48.2 \%$ were female and $31.7 \%$ were male. Sexual functioning were described in this study $\left(\chi^{2}=10.91\right.$, $\mathrm{df}=383, p<0.001)$ as significantly associated to depression disorder. In other study in this year, it was observed in 150 patients, $34.7 \%$ reported positive on at least 1 of the depression inventory, anxiety, and eating disorder; $14.7 \%$ screened positive on 2 of the instruments. $11 \%$ of participants resulted positive for depression. Results showed that $21 \%$ of participants had scores for an anxiety disorder and, finally, $20.7 \%$ reported eating disorder [15]. De Ornelas et al. in 2013 [16], reported 210 patients who were evaluated and divided in two groups, patients with Type $1 / 2$ diabetes. This study showed that patients with type 1 have $60.3 \%$ of anxiety and $67.3 \%$ of depression compared with type 2 anxiety (52.1\%) and depression (52.3\%). However, these patients presented decreased quality of life $(\mathrm{F}=11.78 ; p<0.001)$, whether in their overall assessment or in any of physical $(\mathrm{F}=11.77 ; p<0.001)$ and psychological $(\mathrm{F}=7.40 ; p<0.001)$ domains $[16]$.

In other research, 110 individuals with type 1 diabetes, Maia et al. [17] found 22.7\% GAD; 18.2\% Dysthymia; 8.2\% Current Depression; 5.5\% Panic Disorder; 5.5\% Social Phobia and 4.5\% life-long depression as psychiatric comorbidity. These findings of anxiety generalized disorder and dysthymia in this population were highlighted in this study [17]. Tüzün et al. [18] observed in 74 patients poor quality of life when means were described 65.6 physical; 61.9 psychological; 61 social relationship and 58.9 environmental domains. Otherwise, means were 53.2; 55.8; 55.2 and 54.5, respectively in 51 patients with diabetes and hypertension as well. Handley et al. in 2015 [19], published significant results about depression and suicide ideation among participants with Type 2, insulin-using $(M=27.98 ; p<0.001)$. Between those participants the criteria for likely depression was $38-43 \%$ than among those with no/ mild depressive symptoms were 5-7\%. Evidently, depressive symptoms also were significantly stronger in participants who were reporting suicide ideation $[M=13.1 \pm 5.5]$ than those who did not those kind of ideation $[M=5.1 \pm 4.5 ; F(1,3281)=1203.9 ; p<0.001]$ [19]. 
Van Dooren et al. [20] reported a research with 864 patients with Type $1 / 2$ diabetes had higher levels of depressive and anxiety symptoms, odds ratios $(95 \% \mathrm{CI})$ were 3.15 (1.49; 6.67), 1.73 (0.83-3.60), 1.50 (0.723.12), for PHQ-9 $\geq 10$, current depressive disorder and GAD-7 $\geq 10$, respectively. In the same year, Sun et al. [32] studied 893 participants and found $56.1 \%$ of anxiety symptoms and $43.6 \%$ of depressive symptoms. The highest anxiety scores were more prevalent in women, with lower social status and income, chronic disease, depression and poor sleep quality. Finally, Prinz et al. [21], screened 48700 patients with diabetes have $41.5 \%$ of depression, anxiety/obsessive-compulsive disorder (41.4\%) or needle phobia $(75.8 \%)$ compared with patients without diabetes $(34.6 \%)$ had significantly correlation $(p<0.05)$. Patients who had not mental disorders presented depression scores (8.2\%), anxiety/ $\operatorname{OCD}(6.0 \%)$, or needle phobia (5.3\%) [21].

\section{Prospective Observational Studies [6]}

Chaudhry et al. [22] showed that overall $84 \%$ of subjects with diabetes had comorbid depression. They found that moderate to severe depression was more prevalent in females (71.43\%) compared as males (54.55\%). About anxiety, male had a higher percentage in mild symptoms $(81.8 \%)$ compared as females $(66.7 \%)$, whereas a moderate to severe level of anxiety symptoms is two-times higher in females (39.25\%) compared as males (18.18\%) [22]. Bajor et al. [23] studied a sample of 157 people with diabetes, roughly half $(\mathrm{N}=77)$ carried a diagnosis of major depression, with the remainder divided evenly between schizophrenia disorder $(\mathrm{N}=40)$ and bipolar disorder $(\mathrm{N}=40)$. Fifty-two (33.1\%) had at least one comorbid anxiety diagnosis [23].

Shin et al. [24] screened that $51.6 \%$ patients with diabetes had mental/emotional disorder or alcohol/drug abuse, $37.4 \%$ participants with diabetes and serious psychological distress sought help from general practitioner/primary care physician, while $31.1 \%$ did from mental health providers. Although, patients with diabetes are more likely to take medication for mental health $(57.9 \%$ vs. $53.8 \%)$ the findings showed that were less likely to perceive that they need to see a therapist or psychiatrist compared to those with serious psychological distress only ( $54.7 \%$ vs. $67.8 \%, p=0.02)$ [24]. Chien and Lin [25] found in a sample of 1000000 individuals with diabetes that anxiety disorder was higher than that in the general population $(11.89 \%$ vs. $5.92 \%$, odds ratio, 1.23 ; $95 \%$ confidence interval, 1.17-1.28). The average annual incidence of population who has diabetes with anxiety disorders was also higher than that in the general population $(2.25 \%$ vs. $1.11 \%$, risk ratio $1.34 ; 95 \%$ confidence interval, $1.28-1.41$ ) from 2006 to 2010 [25].

In 2016, Garcia et al. [26], studied in 1586 patients with diabetes who had a $35 \%$ higher rate of depressive symptoms or starting treatment with an antidepressant (hazard ratio $(\mathrm{HR})=1.35,95 \%$ confidence interval $(\mathrm{CI})=1.13-1.62)$. Results were associated with a lower rate of regression from depressed to normal $(\mathrm{HR}=0.72,95 \% \mathrm{CI}=0.59-0.88)$ and a 2.3 greater rate of progression from depressed to death $(\mathrm{HR}=2.31$, $95 \% \mathrm{CI}=1.57-3.40$ ) [26]. The last prospective study in 2016, Whitworth et al. [27] reported the significant correlation of severe psychological symptoms in GAD and Major depressive disorder (MDD) with high hyperglycaemical in type 2 diabetes. The authors showed in 1285 individuals with diabetes type 2 had mild severe depressive symptoms (34.2\%) and $15.7 \%$ were using antidepressant drugs in the baseline. There was a higher correlation in lifetime major depression disorder with current depression symptom $(B=3.16, p<0.001)$. The presence of lifetime GAD was associated with the severe current depression, as well, when patient had high hyperglycaemical $(p<0.001)$ [27].

\section{Retrospective Observational Studies [3]}

Solli et al. [28] evaluated about comorbidities and quality of life in 1000 participants with diabetes. The main goal of this study was use EQ-5D instrument, because it has five dimensions (mobility, self-care, usual activities, pain/discomfort and anxiety/depression) and three levels on each dimension, and has previously been used in diabetes patients. In total $10 \%$ of type 1 patients with diabetes had problems with mobility as judged from the EQ-5D, 3\% with self-care, 19\% with usual activities, $34 \%$ with pain/discomfort and $35 \%$ with anxiety/ depression. For type 2 subjects with diabetes were $26 \%, 6 \%, 25 \%, 45 \%$ and $33 \%$, respectively [28].

Atlantis found a great association in psychopatology and diabetes since Census 2001. According this study, changes over time, specifically in socio-demographic and lifestyle covariates, the strength of these odds ratios were attenuated and ranged from 1.32 $(0.90-1.95)$ to $2.24(1.49-3.36)$ and $1.16(0.99-1.36)$ to $1.51(1.24,1.83)$ for patients with type $1 / 2$ diabetes. On average, those patients from $1.43(0.98-2.10)$ to $2.44(1.63-3.64)$ and $1.32(1.13-1.53)$ to $1.67(1.39$ 2.02) for population without psychopathology by any definition independent of socio-demographic covariates, consistently over the 8 -year period (odds ratios with 95\% confidence intervals $(95 \% \mathrm{CI}$ ) [29]. Gemeay et al. [30] in a sample of 100 patients with diabetes discovered that more than $37 \%$ from Type 1 and $37.9 \%$ from Type 2 patients have severe depression. Those results reported that, although there was no statistically significant difference correlation between patients with Type $1 / 2$ diabetes and level of depression $(p=0.040)$. Concerning the relation between patient's perceptions of changes in body image, indicates that more than $50 \%$ of type 1 patients were anxious regarding changes in body image, while $2.3 \%$ from gestational diabetes felt that their appearance has negatively changed. Among patients without diabetes and types, $48 \%$ of the individuals follow the treatment regimen, while $25 \%$ from the gestational diabetes group never complied. In the same study, concerning late insomnia as a symptoms of depression and types of diabetes, one-third from Type $2(34.5 \%)$ either wake up early in the morning and cannot fall back to sleep, or have no difficulty to sleep again. While more than half (59.3\%) from diabetes Type 1 wake up early in the morning and easily come back to sleep and $43.2 \%$ of those individuals from the gestational diabetes group wake up early in the morning and cannot fall back to sleep [30].

\section{Case Control [1]}

Dos Santos et al. [31] compared type 2 patients with diabetes and patients without diabetes and found presence of $\mathrm{GAD},(\mathrm{OR}=1.77$; $\mathrm{p}<0.001)$, panic disorder or agoraphobia $(\mathrm{OR}=2.31 ; p<0.001)$ and OCD $(\mathrm{OR}=2.47 ; p<0.001)$, with the presence of social phobia being statistically similar between the two groups $(p=0.273)$. This research reported higher significantly correlation and also an interaction between diabetes and panic disorder, resulting in poorer quality of life in the physical $(\mathrm{F}=372.2 ; p<0.001)$, psychological $(\mathrm{F}=148.2 ; p<0.001)$, social $(\mathrm{F}=514.0 ; p<0.001)$ and environment domains $(\mathrm{F}=374.1$ $p<0.001)$. Other important results were for social phobic patients with diabetes had lower scores in all four quality of life domains (physical $(\mathrm{F}=1706.1 ; \quad p<0.001)$, psychological $(\mathrm{F}=245.9 ; p<0.001)$, social $(\mathrm{F}=10.2 ; p<0.001)$ and environment $(\mathrm{F}=660.1 ; p<0.001))$. In $\mathrm{OCD}$ patients with diabetes scores decreased physical $(\mathrm{F}=392.5 ; p<0.001)$, psychological $(\mathrm{F}=85.0 ; p<0.001)$ and environment $(\mathrm{F}=184.2 ; p<0.001)$ domains; however, scores within the social skills were increased $(\mathrm{F}=6.6 ; p<0.01)[31]$ 


\section{Discussion and Conclusion}

In these present exploratory results of mental disorders in subjects with diabetes about anxiety symptoms and anxiety disorders [14-16,18,23-26,32], we found some relevant points. There was a high prevalence in social phobia, panic disorders or agoraphobia, psychological distress, OCD and GAD in type 1 patients with diabetes compared with type 2 [14-16,21,31,32]. Type 1 population with diabetes appears since childhood and it possible that increase in glucose and indicated as predictive of high anxiety [18,23-30]. Also, they must have frequent self-monitoring and reasonable application of injectable insulin by the glucose level may contribute to this higher prevalence of anxiety present in type 1 patients [30,31]. As the results of this study showed, both types require a warning for the treatment of that emotional disturbance $[14,15,26,32]$. Worry about the future is common in patients with diabetes [14-16,21,31,32,33]. All of the time, they can get in troubles with effort, money, and stress have an emotional influence on individual stability and introduce psychiatry disorders. Anxiety disorders cause excessive anxiety and worry about the situation of life, usually without an apparent cause. It is necessary a more rigorous treatment during the chronic phase of the disease, with the purpose of preventing other physiological and emotional comorbidities over patients' lifetime. On a relevant point of this study was insulin helps the body use glucose as an energy source. In insulin resistance, there are inaccuracies in cells about the efficient use of hormone, resulting in high blood sugar $[9,34]$.

Diabetes occurs when the body due to the absence of insulin production or the cells does not adequately use the insulin [9]. Diabetes may be more contribute to depression because of an interaction between high blood sugar levels and a neurotransmitter associated with depression, in this population. The study found that women with depressive symptoms had a $17 \%$ higher risk of developing diabetes and women who use antidepressants had a $25 \%$ higher risk of developing diabetes than those who had not depressive symptoms [35]. This study also found that women with diabetes had a $29 \%$ higher chance of depression and women use insulin had a 53\% higher risk of depression compared with women patients without diabetes [35-41]. When insulin is not working well, high blood sugar levels build in the body and the consequence of that is comorbidity in several areas, eyes, heart and mental disorders. The association between depression symptoms and mood disorders with diabetes was found in several studies [14-18,20$23,26,28,30,32,42]$. Specifically were cited in studies there were $18.2 \%$ participants with Dysthymia $[14,17,18]$. Current $8.2 \%$ with depression $52 \%$ with Major depression as comorbidity in diabetes [14,17,23]. Risk of suicide appears as a consequence of those mental disorders in some of those studies $[14,15,17,18,30]$. Several studies suggest that diabetes doubles the risk of depression compared to those without the disorder [1-4,36,39-42]. The chances to appear symptoms of depression increase with worsening diabetes complications [33,37,38,40-42]. Researchers reported that depression contributes to poorer physical and mental functioning, so a person who has diabetes is less likely to comply with a required diet or medication plan $[17,20,28]$.

In general, endocrinologists when are treating the population with diabetes, wish the success of this quality of life improvement efforts, but they depend on the management will be able to take multiple medicines comprise comprehensive diabetes care. Distress, somatic symptoms, health beliefs, social support and personality traits, can have a direct or indirect impact on individual life with diabetes. Studies were surprising about the overall quality of life in the population with diabetes and their domains physical, psychological, social relationship and environmental
$[16,19,20,28,29,31,42]$. There are other factors affecting recurrent life course in those patients with diabetes included severe depression and anxiety $[9,11]$. They must have regular exams for evaluation of the eyes, feet, heart, and kidneys; they can contribute to reducing the risk for patients without diabetes [9,11]. It is essential that they learn and understand the self-care and seeking preventive health services regularly. In addition, a study with 1160 individuals with cardiovascular risks and diabetes showed an improvement in their clinical and emotional health. It was a primary health care with doctor monitories (project Leonardo). This project reported a guideline that increased patient health knowledge, self-management skills and readiness to make changes in health behaviors [43]. The most important plan is based on the understanding that emotions and physical health are connected. The evidence in literature means that having a healthy emotional life and excellent coping skills will contribute that population to live longer and with better quality of life. Diabetes causes emotional disorders in all patients, but not in the same way. Differences in psychological factors can be noted in patients with Type $1 / 2$ diabetes, such as problems with anxiety and depression disorders. Also, diabetes also affects all domains of quality of life: physical, emotional, environmental and social. Uncontrolled blood sugar levels lead to substantial psychological distress, negative moods, cognitive difficulties, irritable or aggressive behavior, and closely associated problems with social relationships, self-image and self-confidence.

The patient's age, poor glucose control and the duration of diabetes mellitus are predictors of depression. The hypersomnia or insomnia, depression, anxiety disorders and suicide risk are factors that correlated significantly with the general well-being of patients with diabetes. Depression and medical comorbidities have a direct correlation with the quality of life. Psychiatric diseases have significant effects on patients' quality of life and should have an attention in diabetes treatment as well. Treatment of mental disorders with psychotherapy, medication or a combination of these treatments can improve quality of life and selfcare in diabetes.

\section{Acknowledgement}

The contribution of all the authors for the project and production of the article was the selection of articles on the web; implementation the text in Mental Health in Patients with Diabetes and revision of the manuscript.

\section{Conflict of Interest}

All the authors have no conflict of interest and they didn't have grant for this research project.

\section{References}

1. Alt $Y$, Grimm A, Schlegel L, Grambihler A, Kittner JM, et al. (2015) The Impact of liver cell injury on health-related quality of life in patients with chronic liver disease. PLoS One 11: e0151200.

2. Park S, Cho MJ, Chang SM, Bae JN, Jeon HJ, et al. (2010) Relationships of sleep duration with sociodemographic and health-related factors, psychiatric disorders and sleep disturbances in a community sample of Korean adults. J Sleep Res 19: 567-577.

3. Jang SI, Lee KS, Park EC (2013) Relationship between current sleep duration and past suicidal ideation or attempt among Korean adolescents. J Prev Med Public Health 46: 329-335.

4. Park JH, Yoo JH, Kim SH (2013) Associations between non-restorative sleep, short sleep duration and suicidality: findings from a representative sample of Korean adolescents. Psychiatry Clin Neurosci 67: 28-34.

5. Chyun DA, Melkus GD, Katten DM, Price WJ, Davey JA, et al. (2006) The association of psychological factors, physical activity, neuropathy and quality of life in type 2 diabetes. Biol Res Nurs 7: 279-288.

6. Lloyd CE, Dyer PH, Barnett AH (2000) Prevalence of symptoms of depression and anxiety in a diabetes clinic population. Diabet Med 17: 198-202. 
7. Regier DA, Rae DS, Narrow WE, Kaelber CT, Schatzberg AF (1998) Prevalence of anxiety disorders and their comorbidity with mood and addictive disorders. $\mathrm{Br}$ J Psychiatry Suppl 34: 24-28.

8. American Psychiatric Association (2013) Diagnostic and statistical manual of mental disorders.

9. Dreber H, Reynisdottir S, Angelin B, Hemmingsson E (2015) Who is the treatment-seeking young adult with severe obesity: A comprehensive characterization with emphasis on mental health. PLoS One e0145273.

10. Badescu SV, Tataru C, Kobylinska L, Georgescu E, Zahiu DM,et al. (2016) The association between Diabetes mellitus and Depression. J Med Life 9: 120-125.

11. Vanstone M, Rewegan A, Brundisini F, Dejean D, Giacomini M (2015) Patien perspectives on quality of life with uncontrolled type 1 diabetes mellitus: $A$ systematic review and qualitative meta-synthesis. Ont Health Technol Assess Ser 15: 1-29.

12. Moher D, Liberati A, Tetzlaff J, Altman DG (2009) Preferred reporting items for systematic reviews and meta-analyses: The PRISMA statement. PLoS Med 6 : e1000097.

13. Maia AC, Braga AA, Brouwers A, Nardi AE, Oliveira e Silva AC (2012) Prevalence of psychiatric disorders in patients with diabetes types 1 and 2 . Compr Psychiatry 3: 1169-1173.

14. Bener A, Ghuloum S, Abou-Saleh MT (2012) Prevalence, symptom patterns and comorbidity of anxiety and depressive disorders in primary care in Qatar. Soc Psychiatry Psychiatr Epidemiol 47: 439-446.

15. Niraula K, Kohrt BA, Flora MS, Thapa N, Mumu SJ, et al. (2013) Prevalence of depression and associated risk factors among persons with type-2 diabetes mellitus without a prior psychiatric history: A cross-sectional study in clinical settings in urban Nepal. BMC Psychiatry 13: 309

16. De Ornelas Maia ACC, Braga AA, Paes F, Machado S, Carta MG, et al. (2013) Comorbidity of depression and anxiety: Association with poor quality of life in type 1 and 2 diabetic patients. Clin Pract Epidemiol Ment Health 9: 136-141.

17. Maia ACCO, Braga AA, Paes F, Machado S, Nardi AE, et al. (2014) Psychiatric comorbidity in diabetes type 1: A cross-sectional observational study. Revista da Associacao Medica Brasileira 60: 59-62.

18. Tuzun H, Aycan S, İlhan MN (2015) Impact of comorbidity and socioeconomic status on quality of life in patients with chronic diseases who attend primary health care centres. Cent Eur J Public Health 23: 188-194.

19. Handley TE, Ventura AD, Browne JL, Rich J, Attia JR, et al. (2015) Suicida ideation reported by adults with Type 1 or Type 2 diabetes: Results from Diabetes MILES-Australia. Diabet Med 33: 1582-1589.

20. Van Dooren FE, Denollet J, Verhey FR, Stehouwer CD, Sep SJ, et al. (2016) Psychological and personality factors in type 2 diabetes mellitus, presenting the rationale and exploratory results from The Maastricht Study, a populationbased cohort study. BMC Psychiatry 27: 16-17.

21. Prinz N, Bachle C, Becker M, Berger G, Galler A, et al. (2016) Insulin pumps in type 1 diabetes with mental disorders: Real-life clinical data indicate discrepancies to recommendations. Diabetes Technol Ther 18: 34-38.

22. Chaudhry R, Mishra P, Mishra J, Parminder S, Mishra BP (2011) Psychiatric morbidity among diabetic patients: A hospital-based study. Ind Psychiatry J 19 : 47-49.

23. Bajor LA, Gunzler D, Einstadter D, Thomas C, McCormick R, et al. (2015) Associations between comorbid anxiety,diabetes control and overall medical burden in patients with serious mental illness and diabetes. Int J Psychiatry Med 49: 309-320.

24. Shin JK, Poltavskiy E, Kim TN, Hasan A, Bang H (2016) Help-seeking behaviors for serious psychological distress among individuals with diabetes mellitus: The California health interview survey, 2011-2012. Primaire Care Diabetes 11: 63-70.
25. Chien IC, Lin CH (2016) Increased risk of diabetes in patients with anxiety disorders: A population-based study. J Psychosom Res 86: 47-52.

26. Garcia ME, Lee A, Neuhaus J, Gonzalez H, To TM, et al. (2016) Diabetes Mellitus as a risk factor for development of depressive symptoms in a population-based cohort of older Mexican Americans. J Am Geriatr Soc 64: 619-624.

27. Whitworth SR, Bruce DG, Starkstein SE, Davis WA, Davis TME, et al. (2017) Depression symptoms are persistent in Type 2 diabetes: Risk factors and outcomes of 5 year depression trajectories using latent class growth analysis. Diabet Med 34: 1108-1115

28. Solli O, Stavem K, Kristiansen I (2010) Health-related quality of life in diabetes: The associations of complications with EQ-5D scores. Health Qual Life Outcomes 8: 18

29. Atlantis E (2012) Excess burden of type 1 and type 2 diabetes due to psychopathology. J Affect Disord 142: S36-41.

30. Gemeay EM, Moawed SA, Mansour EA, Ebrahiem NE, Moussa I, et al. (2015 The association between diabetes and depression. Saudi Med J 36: 1210-1215.

31. Dos Santos MAB, Ceretta LB, Reus GZ, Abelaira HM, Jornada LK, et al. (2014) Anxiety disorders are associated with quality of life impairment in patients with insulin-dependent type 2diabetes: A case-control study. Rev Bras Psiquiatr 36 298-304.

32. Sun N, Lou P, Shang Y, Zhang P, Wang J, et al. (2016) Prevalence and determinants of depressive and anxiety symptoms in adults with type 2 diabetes in China: A cross-sectional study. Br Med J Open 6: e012540.

33. Ciechanowski PS, Katon WJ, Russo JE (2000) Depression and diabetes: impact of depressive symptoms on adherence, function, and costs. Arch Int Med 160: 3278-3285

34. Lewko J, Kochanowicz J, Zarzycki W, Mariak Z, Górska M, et al. (2012) Poor hand function in diabetics. Its causes and effects on the quality of life. Saud Med J 33: 429-435.

35. Wang MY, Tsai PS, Chou KR, Chen CM (2008) A systematic review of the efficacy of non-pharmacological treatments for depression on glycaemic control in type 2 diabetics. J Clin Nurs 17: 2524-2530.

36. Mosaku K, Kolawole B, Mume C, Ikem R (2008) Depression, anxiety and quality of life among diabetic patients: A comparative study. J Natl Med Assoc 100: 73-78.

37. BundoVidiella M, AubaLlambrich J, MassonsCirera J, Trilla Soler MC, Perez Villegas R, et al. (1996) Anxiety and depression in type II diabetics. Atencao Primaria 17: 58-62.

38. Lyoo IK, Yoon S, Jacobson AM, Hwang J, Musen G, et al. (2012) Prefrontal cortical deficits in type 1 diabetes mellitus: brain correlates of comorbid depression. Arch Gen Psychiatry 69: 1267-1276.

39. Bernstein CM, Stockwell MS, Gallagher MP, Rosenthal S, Soren K (2013) Mental health issues in adolescents and young adults with type 1 diabetes: Prevalence and impact on glycemic control. Clin Pediatr (Phila) 52: 10-15.

40. Liu X (2014) Sleep and adolescent suicidal behavior. Sleep 27: 1351-1358.

41. Blasco-Fontecilla $H$, Alegria AA, Lopez-Castroman J, Legido-Gil T, Saiz-Ruiz J, et al. (2011) Short self-reported sleep duration and suicidal behavior: A crosssectional study. J Affect Disord 133: 239-246.

42. Breslau N, Roth T, Rosenthal L, Andreski P (1996) Sleep disturbance and psychiatric disorders: A longitudinal epidemiological study of young adults. Biol Psychiatry 39: 411-418

43. Ciccone MM (2010) Feasibility and effectiveness of a disease and care management model in the primary health care system for patients with heart failure and diabetes (Project Leonardo). Vasc Health Risk Manag 6: 297-305.

44. van Dijk PR, Logtenberg SJ, Groenier KH, Keers JC, Bilo HJ, et al.(2014 Fifteen-year follow-up of quality of life in type 1 diabetes mellitus. World $J$ Diabetes 15:569-576. 